\title{
ODONTOLOGINĖS PRIEŽIŪROS IR BURNOS HIGIENOS STUDIJŲ PROGRAMŲ ABSOLVENTŲ KOMPETENCIJŲ ATITIKTIS DARBO RINKOS POREIKIAMS
}

\author{
Irma Spiriajevienė, Kristina Albrechtienė, Jurgita Andruškienė \\ Klaipèdos valstybinès kolegijos Sveikatos mokslu fakulteto Burnos priežiüros ir mitybos katedra
}

Raktažodžiai: absolventų kompetencijos, Odontologinès priežiūros studijų programa, Burnos higienos studijų programa, darbo rinkos poreikiai, focus grupès tyrimas, kontentinè analizè, kokybinis tyrimas.

\section{Santrauka}

Tyrinejamai temai analizuoti buvo atlikta literatūros ir dokumentų analizè bei focus grupès tyrimas. Tikslas - išanalizuoti darbdavių / socialinių partnerių požiūrị i Odontologinès priežiūros ir Burnos higienos studijų programų absolventų kompetencijų atitiktị darbo rinkos poreikiams. Empiriniai duomenys rinkti darbdavių / socialinių partnerių apskritojo stalo diskusijos metu, taikant focus grupès interviu metodiką. Tyrime dalyvavo 11 odontologijos srities specialistu - ekspertų. Empiriniams duomenims analizuoti atlikta kokybinè kontentinè analizè.

Rezultatai. Išanalizavus kokybinio tyrimo duomenis, išskirtos šios kategorijos: „Aukštojoje mokykloje igyti profesinès kompetencijos pradmenys ugdomi ir tobulinami bedirbant“" (19 teiginių), ,Socialiné kompetencija koncentruojasi profesinio bendravimo su klientais ir kolegomis segmente" (19 teiginių), „Bendrujų kompetencijų tobulinimo perspektyvos" (6 teiginiai), „Absolventų motyvacijos svarba jų kompetencijų plètotei - prioritetinè vertybe்" (6 teiginiai), „Emocinio intelekto kompetencija orientuota i lankstumą ir prisitaikymą prie gydytojo" (6 teiginiai), „Bendravimas ir kitos kompetencijos priskiriamos tęstinèms gyvenimo bei darbo kompetencijoms, nesikoncentruojant ị konkrečią ugdymosi instituciją “ (5 teiginiai), „Burnos higienos ir odontologinès priežiūros profesijų poliariškumas ir kompetencijų subalansavimo perspektyvos“ (5 teiginiai), „Naujų, progresyvių edukacinių sričių plètotè ir atitinkamų kompetencijų stiprinimas“ (4 teiginiai), „Diskusijos apie absolventų kompetencijų atitiktį darbo rinkai poreikis" (7 teiginiai).

Tyrimo dalyvių diskusija koncentruojasi iš kategorijų sudarytose šiose pagrindinėse subkategorijose: „Prioritetas profesinio bendravimo kompetencijai” (9 teiginiai), ,Praktiniu igūdžiu poreikis ir praktikos galimybès“ (6 teiginiai), ,Tobulinimosi motyvacijos siekiamybè - nuolat besimokančios visuomenès poreikis“ (4 teiginiai), „Darbo komandoje kompetencijos svarba ir plètoté" (4 teiginiai). Visos kitos 23 subkategorijos sudarytos iš mažesnès koncentracijos diskusijoje teiginių (kiekvienai subkategorijai skirti 2-3 teiginiai).

\section{İvadas}

Gyvendami visuomeneje, žmonès vadovaujasi tuo, dèl ko, jų nuomone, yra verta gyventi ir kas ịprasmina gyvenimą (1). İsitraukimas ị darbinę veiklą yra vienas iš žmonijos gerovès garantų. Tačiau, kaip rašè mąstytojas Vydūnas, tautai labai daug reiškia, kad darbas būtų atliekamas ịvertinant žmogaus pasišventimą bei gabumus (2). Nors gana aišku, kad dvi svarbios žmoniu gyvenimo sritys - veiklos sistema (darbas) ir švietimas - yra glaudžiai susiję, jų santykiai ilgai stokojo konkretesnès išraiškos (3). Vieni svarbiausių šių santykių subjektų yra studentai ir dirbantieji, kurių pasirengimą dirbti laiduoja švietimo sistema, suteikianti darbui reikalingas ir žmogui tinkamas kompetencijas.

Darbo pasaulyje susiduriame su naujais nuolat kintančiais reikalavimais darbuotojui, jo vaidmens didejjimu. Vienas iš šiuolaikinių kaitos aspektų yra augantys visuomenès darbo kokybės lūkesčiai. Šiuolaikinè profesinè veikla reikalauja tam tikros profesinès specializacijos, kuri atitiktu darbo rinkos poreikius ir darbuotojai turètų tas kompetencijas, kurios padètų lengviau integruotis į darbinę veiklą. Siekiant savo ugdymosi rezultatus pritaikyti praktikoje, aukštosioms mokykloms reikia pasitelkti socialinę partnerystę ir darbdavius kaip perspektyvaus bendradarbiavimo su darbo pasauliu garantą. 
Sveikatos priežiūros kokybẻ turi būti grindžiama geresniu pacientų poreikių tenkinimu, profesionalių specialistų pritraukimu, išteklių (taip pat ir žmogiškujų) subalansavimu, išlaikymu esamų ir pritraukimu naujų klientų bei, apskritai, išlikimu bei kryptingu vystymusi.

Gydytojų odontologu padejëjų bei burnos higienos specialistų vaidmuo odontologijoje yra labai svarbus dèl visuomenèje didèjančio rūpinimosi savo sveikata, dèl populiarèjančio naudojimosi odontologijos ir profesionaliosios burnos priežiūros paslaugomis ir tokiu būdu tendencingai augančio klientų, besilankančių odontologijos institucijose, skaičiaus. Tokiuose sveikatos priežiūros darbuose, Y. N. Harari (4) teigimu, kur reikalaujama plataus ịgūdžių spektro ir kur tenka susidurti su įvairiais nenumatytais scenarijais, panašu ị tai, kad ir ateityje žmones pakeisti dirbtiniu intelektu bus daug sunkiau nei kituose darbuose. Taigi, ir ši odontologinès priežiūros sritis veikiausiai dar ilgą laiką išliks žmoniu bastionu, o tyrimai nestokos aktualumo ir populiarumo. Šio tyrimo aktualumą sustiprina ir neseniai Lietuvoje atliktu keleto mokslinių tyrimų rezultatai, kurie rodo susidariusią gana problematišką situaciją gydytojų odontologų padejējų atžvilgiu. Kaip teigia R. Tamulienè, D. Mačiulienè ir V. Žukauskaitė (5), apklaususios 73 gydytojo odontologo padèjèjus, 47,2 proc. gydytojų odontologų padejëjų pasitenkinimo darbu lygmuo yra labai žemas, o labai aukšto - nenustatyta. Kito mokslino tyrimo (6), kuriame dalyvavo 62 dirbantys gydytojų odontologų padejjèjai, rezultatai atskleidè, kad odontologų padejjejų darbe yra patiriamas vidutinio lygmens stresas, artejantis prie aukšto streso lygmens. Be to, abiejuose moksliniuose tyrimuose jaunesnio amžiaus ir mažesni darbo stažą turinčių darbuotojų pasitenkinimo darbu lygmuo yra mažesnis, o patiriamo streso - didesnis nei vyresniujų ir turinčiujų didesnị darbo stažą $(5,6)$. Visa tai suponuoja tokią situaciją, kad kai kuriuose tirtuose Lietuvos regionuose jauni ir nedidelę darbo patirtị turintys darbuotojai, iš kuriu daugelis neseniai yra baigę gydytojų odontologų padejejų, burnos priežiūros bei kitas studijas, sudaro probleminę darbuotoju grupę. Tai sustiprina poreikị išanalizuoti ir kitu miestų odontologų padejejęų bei burnos priežiūros specialistų, kuriuos ruošia aukštosios mokyklos - šiuo atveju Klaipèdos valstybinè kolegija, situaciją.

Klaipėdos valstybinès kolegijos Sveikatos mokslų fakultete pagal Odontologinès priežiūros (17 metų) ir Burnos higienos studijų (7 metai) programas yra ruošiami studentai. Daugelis šios aukštosios mokyklos absolventų dirba ịvairiose odontologinėse struktūrose. Remiantis šiuolaikine mokymosi visą gyvenimą paradigma, mokymo ir studijų programos turi būti pagrịstos nuolatine kompetencijų peržiūra, kompetencijų ugdymu ir plètote. Taigi, verta išsiaiškinti, ar absolventų kompetencijos atitinka socialinių partnerių / darbdavių profe- sinius lūkesčius ir išanalizuoti, koks yra ịvairių kompetencijų pagal studijų programas atitikimas darbo rinkai. Mokslinè darbo rinkos ir studijų programų ryšio atitikties analizè gali suteikti kompetencijų ugdymo kryptis, kad programos būtu tobulinamos ir kuo labiau atitiktų šiandieninès darbo rinkos poreikius bei užtikrintų tinkamą burnos priežiūros paslaugų teikimą. Taigi, atsiranda abipusis poreikis grįžtamajam ryšiui iš socialinių partnerių / darbdavių perspektyvos.

Darbo tikslas - išanalizuoti socialinių partnerių / darbdavių požiūrị ị Odontologinès priežiūros ir Burnos higienos studijų programų absolventų kompetencijų atitikti darbo rinkos poreikiams.

\section{Tyrimo metodika}

Šiame tyrime duomenims rinkti ir analizuoti buvo naudoti literatūros ir dokumentų analizès, focus grupès interviu bei kokybinès kontentinès analizès metodai. Aukštosios mokyklos studijų dokumentuose (Odontologinès priežiūros ir Burnos higienos studijų programų aprašai) yra patvirtintos studentų kompetencijos, ị ką aukštoji mokykla orientuojasi, ruošdama studentus. Šių dokumentų analizès pagrindu sukonstruotas atvirų klausimų interviu. Empirinis focus grupès interviu tyrimas vyko apskritojo stalo diskusijos pagrindu. Focus grupés tyrime dalyvavo vienuolika socialinių partneriu / darbdavių (ekspertų), 8 - moterys ir 3 vyrai. Jų amžiaus vidurkis - 45,1 metų. Tiriamujų grupei sudaryti buvo taikomas kriterinès atrankos metodas, atsižvelgiant ị šiuos kriterijus: laikomasi profesijos burnos priežiūros srityje kriterijaus ir pagal profesiją šiuo metu dirbamo darbo kriterijaus. Tyrime dalyvavo odontologijos srities specialistai: gydytojai odontologai, odontologijos klinikų vadovai, gydytojo odontologo padèjèjai, burnos priežiūros specialistai, odontologijos klinikos vadybininkas, Lietuvos burnos higienistų draugijos atstovas, SPC higienistas. Vidutinè ekspertų darbo patirties trukmè burnos priežiūros srityje - 17,4 metų. Interviu buvo fiksuojamas diktofonu. Transkribuotas tekstas gavo dokumento statusą, o pagal sukūrimo laiką (interviu vyko neseniai) ir autorystę (išrašo autoriai - focus grupès tyrimo komandos nariai) dokumentą galima priskirti pirminiam šaltiniui (7).

Focus grupès tyrimo dokumentas analizuojamas taikant kokybinę kontentinę analizę. Tyrimo dalyviams skirti identifikavimo kodai. Duomenys skaidomi, grupuojami, sukuriamos kategorijos, subkategorijos, joms priskiriami dalyvių teiginiai. Šis procesas fragmentuota forma formuoja duomenų bazę, duomenys skirstomi pagal atskirus kriterijus, ịvairiomis dimensijomis, skirtingais pjūviais. Tai tyrime turi ypatingai svarbią reikšmę kaip išskirtinis procesas, dẻl to prie jo grižžtama tiek kartų, kiek jaučiamas poreikis, kol manoma, kad analitinis duomenų tvarkymo potencialas dar neišsemtas 
(7). Taigi, kategorijų ir subkategorijų pavadinimai kinta daug kartų, kol galutinai ,išsigrynina“. Pasitelkus komandą, atliekamas duomenu priskyrimo kategorijoms ir subkategorijoms filtravimas. Atliekant tyrimą buvo nuosekliai rūpinamasi jo validumu. Šiame tyrime vidinis validumas užtikrinamas tokiais būdais: diktofono naudojimu, pačių tyrèjų dalyvavimu duomenų rinkime, transkribavime ir analizeje, duomenų filtravimo mechanizmo naudojimu.

\section{Rezultatai ir jų aptarimas}

Kompetencijos konceptualizavimas. Remiantis E. Durkheimo visuomeninio darbo pasidalijimo samprata, kompetencija yra esminis veiksnys, užtikrinantis harmoningą individo ir visuomenès sąveiką: individai turi užimti tokias darbo vietas, kurios atitinka jų turimas kompetencijas. Nuolat besikeičiantis ir sudètingejjantis socialinis ekonominis kontekstas daro sudètingesnị ir kompetencijos suvokimą. Paskutiniji praejjusiojo šimtmečio dešimtmetị ir šio tūkstantmečio pradžioje kompetencijos (angl. competency) sąvokos interpretavimas tapo ypač populiarus bei problematiškas ir sulaukè ịvairių sričiu mokslininkų dėmesio. Anot prof. R. Laužacko (3), analizuojant kompetencijos sąvoką, daugeliu vartojimo atvejų kompetencija atspindi žmogaus santyki su apibrèžta aplinka ir parodo jo poziciją tam tikros veiklos atžvilgiu. Tam tikriems profesiniams veiksmams atlikti reikalingi konkretūs žmogaus gebejjimai, kurie santykyje su veiklos (darbo) parametrais tampa būtent kompetencijomis (3). Lietuvos Respublikos švietimo ịstatymo pakeitimo ịstatyme kompetencija ịvardijama gebejimu atlikti tam tikrą veiklą, remiantis ịgytų žinių, mokèjimų, igūdžių, vertybių nuostatų visuma.

Žiūrint platesne prasme, kompetencijos koncepto kompleksiškumas sąlygoja be minètưjų žinių, gebèjimų, igūdžių, vertybių dar ir savęs suvokimą, asmenines charakteristikas bei motyvus (8). Burnos priežiūros srityje, pvz., kalbant apie burnos higienos specialistus, atliekama profesionalioji burnos higiena - t. y. higienos procedūros, kurių metu šalinamos mineralizuotos ir nemineralizuotos apnašos, poliruojami dantų ir plombu paviršiai, nustatomas asmens dantų valymo efektyvumas, pacientai mokomi asmens higienos, atliekamos gydomujų preparatų aplikacijos (9). Taigi, kaip vienos svarbiausių, susijusių su paciento sveikata ir psichologine atmosfera burnos priežiūros srityje išskirtinos profesinès kompetencijos, kurios orientuotos ị procedūrinę veiklą bei psichoemocinę sritị. Kompetencija išreiškia, ar besimokantysis įgijo tam tikrų profesiškai reikšmingų kompetencijų. Taigi, kompetencija - profesiškai reikšmingų žinių, mokèjimų, igūdžių, patyrimo, požiūrių, asmeninių charakteristikų ir vertybių visuma.

Gydytojų odontologų padėjẻjų ir burnos higienos specialistų darbo realijos. Kaip rodo atlikti moksliniai tyrimai (10), 21,9 proc. Lietuvos odontologų dirba visada vieni, 37,4 proc. - kartais dirba su padejeju ir 40,7 proc. - nuolat dirba su padejeju. Pagal atliktus tyrimus (10) 66,4 proc. praktikuojančių odontologu padejjejų turi darbo licenciją ir yra pabaigę odontologų padejejųu studijas, 20,2 proc. odontologų padejjejų yra pabaigę kitas medicinos srities studijas, 8,6 proc. - yra burnos higienistai ir 4,8 proc. - neturi medicininio išsilavinimo. Taigi, didžioji dauguma odontologų dirba visada ar kartais be padejjejjo pagalbos, o kas trečias odontologas, dirbantis su padejjèju, dirba su nesertifikuotu odontologo padejejju (10). Esant tokiai situacijai, tinkamų kompetencijų plètojimas aukštojoje mokykloje, ruošiant gydytojų odontologų padejjejus ir burnos higienos specialistus, būtų viena iš patikimų darbo rinkos užpildymo ir išlikimo konkurencijos sąlygomis priemonių.

Gydytojų odontologų padejejjų ir burnos higienos specialistų kompetencijų kontekste, remiantis mokslinès literatūros analize, akcentuotina ergonomikos darbe svarba, nes, kaip parode kitas mokslinis tyrimas (11), kurio dalyviai buvo dviejų Lietuvos rajonų privačių odontologijos klinikų ir poliklinikų odontologijos skyrių gydytojo odontologo padejejjai, tie respondentai, kurie nurodè, kad jų darbas yra sunkus, kaip svarbiausią priežastị ịvardijo ergonominių principų ir žinių šioje srityje trūkumą. Stokojant ergonomikos pagrindų, tikètina, kad nukenčia darbo efektyvumas, kuris priklauso nuo darbo vietos, tinkamo ịrankių išdèstymo ir pan. Be to, dažnas rizikos veiksnys gydytojo odontologo padejjëjo darbe - stresas, kuri jie patiria bendradarbiaudami su gydytoju odontologu ir kitais atvejais (11). Pastarajame tyrime (11) stresą darbe patiria visi respondentai. Kaip yra žinoma, ittemptoje situacijoje, veikiant stresui, atliekamas darbas stokoja kokybės, efektyvumo ir, anot mokslininkų (12), atlikusių didelès imties ịvairaus profilio aukštujų mokyklų absolventų tyrimą, absolventams labiausiai ir trūksta šios kompetencijos - tinkamai atlikti darbą ítemptoje situacijoje. Taigi, neabejotinai aktuali yra profesinio bendravimo kompetencija, kuri priklauso socialinių kompetencijų grupei ir reiškia bendravimą bei bendradarbiavimą, orientavimąsi sudètinguose socialiniuose santykiuose, sėkmingą darbą su kitais žmonėmis, suprantant ir gerbiant jų interesus. Sėkmingam komunikavimui yra reikalingi ne tik socialiniai, bet ir asmeniniai gebėjimai, pvz., sąžiningumas, savikritiškumas, pasitikejjimas, iniciatyvumas bei atsakingumas. Profesinè ir socialinè kompetencijos sudaro integralios šiuolaikinès karjeros pagrindą, dèl to svarbu atkreipti ypatingą dèmesį i šsų kompetencijų grupių plètojimą. Taigi, svarbu išsiugdyti kompetencijas, kurios užtikrintų sklandų absolventų perejjimą ị darbo rinką ir galètų būti tiesiogiai pritaikomos profesinejje veikloje. 
Aukštojoje mokykloje ịgyti profesinès kompetencijos pradmenys ugdomi ir tobulinami bedirbant (1 pav.). Profesinè kompetencija - gebejjimas veiksmingai dirbti tam tikros rūšies veikloje ir tai tiesiogiai susiję su darbuotojo išsilavinimu, kvalifikacija, patirtimi (8). Tai iliustruoja ir ekspertų pasisakymai focus grupès tyrime:

Pagrindiniai gebejimai atsiranda praktikoje, per stebéjimus ir analize (PO3) ${ }^{1}$. Pagrindinius dalykus jie žino: kaip paruošti darbo vieta, kaip tvarkyti, pakuoti instrumentus ir t. t. Tie gebejimai, berods, yra (PO4). Tas kompetencijas turime tobulinti... klinikine praktika. Kompetencijos yra „uždirbamos “ patirties dèka (PO6).

Profesinès kompetencijos daugiasluoksniškumą bei tęstinumą galima grịsti Vydūno (2) įžvalgomis, kad pradinis žinojimas esąs tarsi atspirties taškas, po to eina giluminis pažinimas, t. y. mokslo teikiamos žinios teatlieka nors ir svarbų, bet tik pagalbinị vaidmenį. Sąvokai „žinios“ apibréžti

${ }^{1}$ Eksperto identifikavimo kodas ( $\mathrm{P}$ - socialinis partneris, darbdavys, $\mathrm{O}$ - Burnos higienos ir/ar Odontologinès priežiūros programos, skaičius eksperto eilès numeris sąraše).

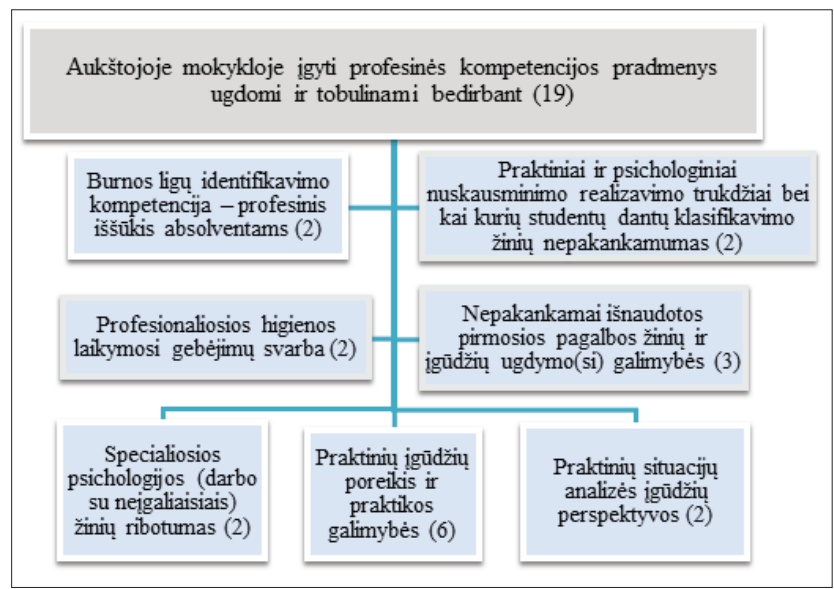

1 pav. Kategorijos „Aukštojoje mokykloje igyti profesinès kompetencijos pradmenys ugdomi ir tobulinami bedirbant" subkategorijos ir patvirtinančių teiginių skaičius.

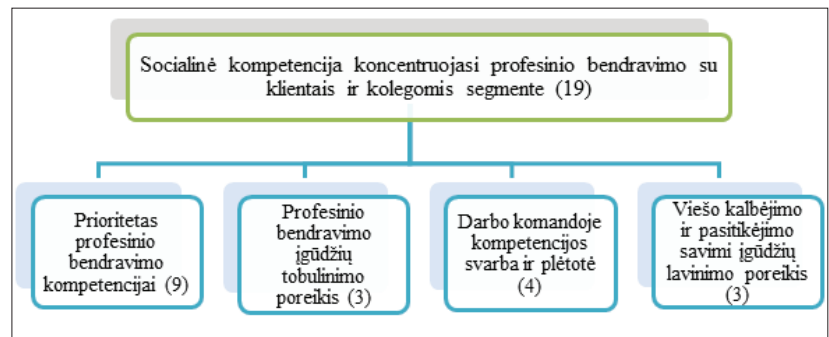

2 pav. Kategorijos „Socialinė kompetencija koncentruojasi profesinio bendravimo su klientais ir kolegomis segmente" subkategorijos ir patvirtinančių teiginių skaičius japonų kalboje vartojamos trys sudedamosios dalys: žinios (jap. chishiki), supratimas (jap. rikai) ir meistriškumas (jap. tsugyo). Šios sąvokos taikomos, kai individas ịgyja žinių, kurios pereina per individo patirti ir tampa jo nuosavybe. Visų studijų programų turinys turetų būti rengiamas taip, kad absolventai išsiugdytų sẻkmingai veiklai reikalingus kompetentingumus arba bent jau turètu ,pagrindus“, sudarančius prielaidas vèliau išsiugdyti reikiamus kompetentingumus darbe (12). Taigi, kai profesine kompetencija ugdoma ir plètojama darbinèje (praktinejje) veikloje, igyjant patirti, pasiekiama aukštesnè profesine dimensija.

Socialinès kompetencijos koncentruojasi profesinio bendravimo su klientais ir kolegomis segmente (2 pav.). Socialine kompetencija atitinka santykių raiškos objektą ir apibūdinama gebejjimu bendrauti ir bendradarbiauti, orientuotis sudètinguose socialiniuose santykiuose, sèkmingai dirbti su kitais žmonèmis, suprantant ir gerbiant jų interesus. Kaip teigia amerikiečių rašytojas P. Block (13), išleidęs nemažai knygų apie komunikaciją sveikatos priežiūros ir kitose srityse, labai svarbūs darbe yra komandiniai ir asmeniniai santykiai ir reikia suteikti formą emociniams ir asmeniniams mūsų pareigybių aspektams, be to, akcentuoja, kad reikia gilintis ị emocinius tarpusavio ryšio aspektus. Socialiai kom-

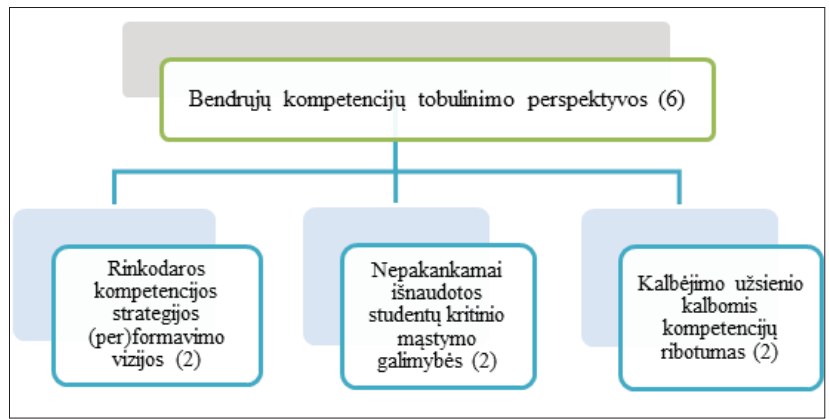

3 pav. Kategorijos "Bendrujų kompetencijų tobulinimo perspektyvos" subkategorijos ir patvirtinančių teiginių skaičius.

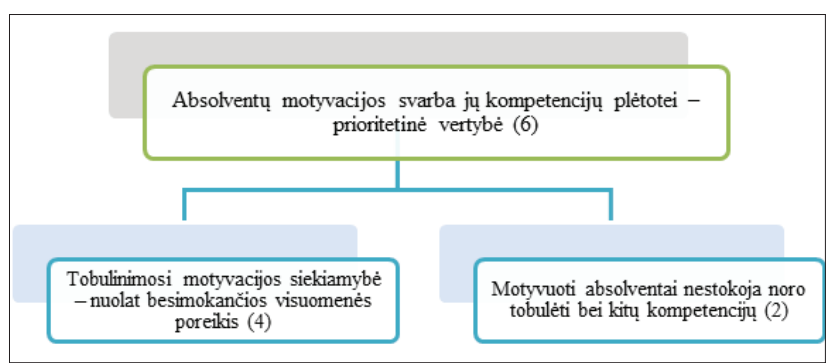

4 pav. Kategorijos „Absolventų motyvacijos svarba jų kompetencijų plètotei - prioritetinè vertybe்“ subkategorijos ir patvirtinančių teiginių skaičius. 
petentingam žmogui būdingi gebejjimai: komunikabilumas, tolerancija, pasitikèjimas savimi, savikritiškumas, savarankiškumas ir kt. Profesinio bendravimo svarba akivaizdi ir tyrimo dalyvių diskusijoje:

BH specialistams reikètu nuo pirmo kurso aiškinti, kad jie turès ne tik manualinius darbus atlikti, bet ir daug kalbèti (PO3). Jei santykiai bus konfliktiški, tai tokiu santykiu ir nebus, nes čia nebus to žmogaus (juokiasi) (PO3). Labai svarbus psichologinis aspektas, komunikacija tiek su klientais, tiek su kolektyvu. $<\ldots>$ Pritariu, turi büti bendravimo kultūra. $<\ldots>$ Norisi

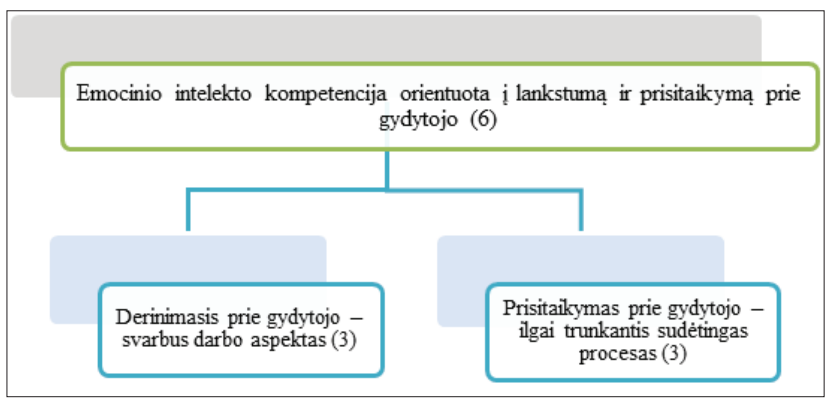

5 pav. Kategorijos „Emocinio intelekto kompetencija orientuota ị lankstumą ir prisitaikymą prie gydytojo" subkategorijos ir patvirtinančių teiginių skaičius.

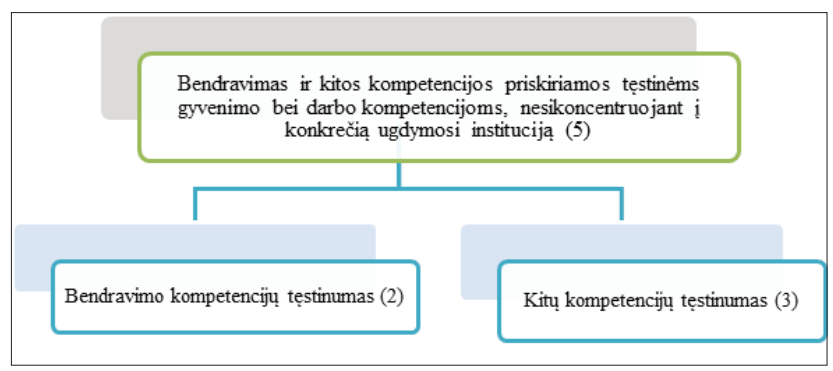

6 pav. Kategorijos „Bendravimas ir kitos kompetencijos priskiriamos tęstinėms gyvenimo bei darbo kompetencijoms, nesikoncentruojant ị konkrečią ugdymosi instituciją" subkategorijos ir patvirtinančių teiginių skaičius.

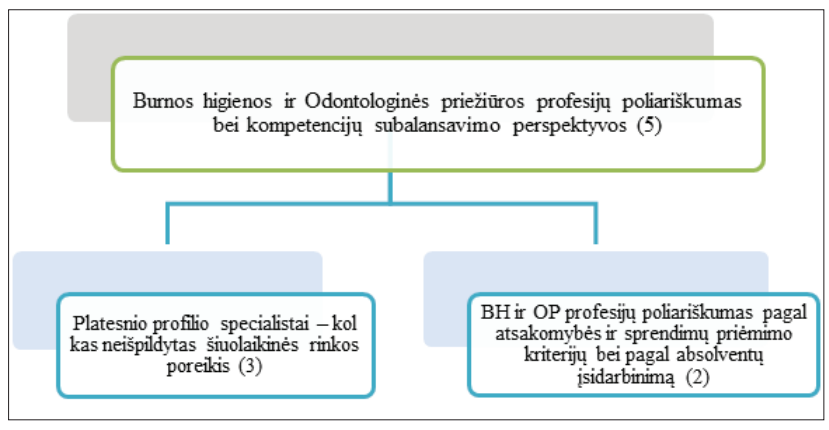

7 pav. Kategorijos „Burnos higienos ir odontologinès priežiūros profesijų poliariškumas ir kompetencijų subalansavimo perspektyvos" subkategorijos ir patvirtinančių teiginių skaičius. ne ,roboto" šalia savęs, o ,gyvo “ žmogaus, kuris dalyvautu, nebijotu klausti (PO8). Tie studentai, kurie ateina pas mus i praktika, labai gerai moka bendrauti ir su klientais, ir su kolektyvu (PO11).

Bendrųų kompetencijų tobulinimo perspektyvos (3 pav.). Siekis išnaudoti bendrujų kompetencijų tobulinimo galimybes užfiksuotas šiuose segmentuose: kritinio mąstymo, kalbėjimo užsienio kalbomis (ypač rusų k.) bei rinkodaros pradmenų. Keletas tyrimo dalyvių išreiškè kalbėjimo užsienio kalbomis kompetencijų svarbą ir ribotumą:

Yra tokiu absolventu, kurie mègina kalbèti ir kalba, o užsieniečiui tai yra labai svarbu. Jei su jais darbuotojas kalba, tai jie nuo jo ir nesitraukia (PO3). Yra daug jaunesnés kartos atstovu, kurie nemoka rusu kalbos. $O$ gyvenančiu rusakalbiu pas mus daug... (PO4).

Akivaizdu, kad absolventų kompetencijos dirbti daugiakultūrèje aplinkoje yra menkiau išplètotos, nei nacionalinėje ir regioninėse aplinkose dirbančiujjų (12). Kalbejjimo užsienio kalbomis kompetencija orientuota ị vieną iš mažiau tirtų, bet aktualių šiuolaikinejje aukštojo mokslo sistemoje kompetencijų, t. y., tarpkultūrinę kompetenciją. Tarpkultūrinė kompetencija suprantama kaip žmogaus gebejjimas, remiantis tam tikromis žiniomis, igūdžiais ir nuostatomis, komunikuoti ir sąveikauti (dirbti) su kitos kultūros, grupès, bendruomenès atstovais $(8,14)$ tokiame kontekste, kurị sąlygoja situacijos, aplinkybės, ịsitraukę žmonés, santykis tarp tų žmonių ir pan. (15). Kaip nurodoma mokslo studijos išvadose (14), jei

${ }^{2}$ Ekspertų teiginių skaičius kategorijoje (bendras) ir subkategorijose.

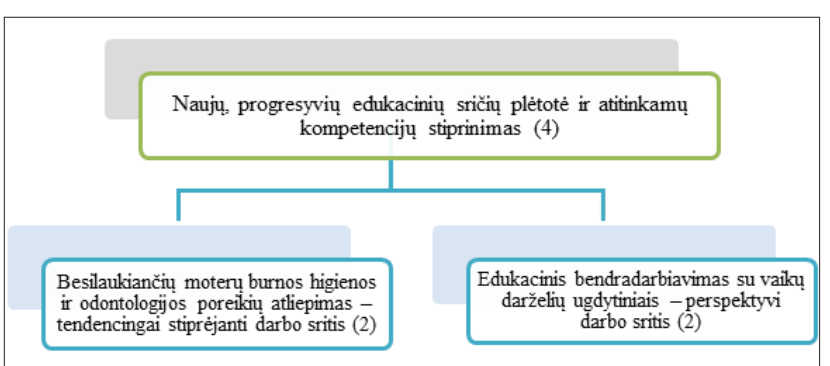

8 pav. Kategorijos „Naujų, progresyvių edukacinių sričių plètotė ir atitinkamų kompetencijų stiprinimas" subkategorijos ir patvirtinančių teiginių skaičius.

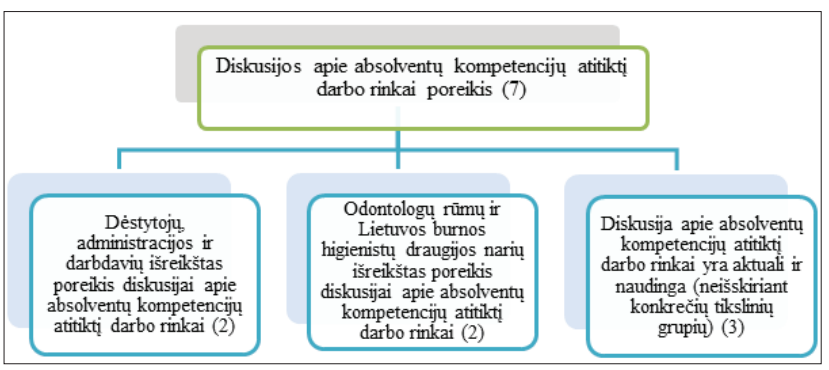

9 pav. Kategorijos „Diskusijos apie absolventų kompetencijų atitiktị darbo rinkai poreikis" subkategorijos ir patvirtinančių teiginių skaičius. 
iki šiol populiariausias būdas ugdyti asmens tarpkultūrines kompetencijas buvo keliavimas ị užsienio šalis darbo, studiju tikslais, tai dabar pastebèta, kad tarpkultūrinè kompetencija taip pat sėkmingai gali būti ugdoma toje pačioje šalyje (ịsitraukiant ar susikuriant kultūriškai skirtingus laukus, per ivairias bendruomenes ir pan.).

Absolventų motyvacijos svarba jų kompetencijų plètotei - prioritetinė vertybė (4 pav.). Daugelio mokslininku teigimu šiuo metu viena iš svarbiausių žmogiškujų ištekliu valdymo dimensijų yra darbuotojų motyvacija, kuri sietina su žmonių elgesio motyvais, t. y. su asmens motyvais siekti gèrio kitiems ir visuomenei, teikiant jiems paslaugas. Dideli poveikị darbo efektyvumui turi žmogiškujų išteklių motyvavimo sistema, siekiant, kad darbuotojai būtų motyvuoti realizuoti savo turimą potencialą. Motyvuojantys darbuotojus veiksniai, mokslininkų teigimu, yra ne tik institucijos motyvacija, materialinès paskatos ar parama, bet ir komandos ryšiai (8). Kita vertus, kiti (pvz., aukštosios mokyklos dėstytojai ar darbdaviai) gali žmogų tik pažadinti, parodyti veikimo kryptị, ar, kaip rašo Vydūnas, sukelti jo norą kopti aukštyn, bet veikti, kopti turi jau pats žmogus, ir būtinai tiktai savo noru ir valia (2). Ekspertų lūkesčiai focus grupès tyrime diskutuojant buvo nukreipti į absolventų tobulëjimo motyvaciją:

Dèstytojai skatina studento žingeidumą, nora tobulintis, išugdo pasididžiavima savo profesija. < ..> Daug tikètis gebejjimu ir žiniu iš ka tik baigusiu studijas absolventu mes negalime, bet norime tikètis ju žingeidumo ir motyvacijos (PO6).

Vykstant nuolatinei veiklos charakteristikų kaitai, žmogus privalo nuolat tobulinti turimą kvalifikacinị potencialą.

Emocinio intelekto kompetencija orientuota ị lankstumą ir prisitaikymą prie gydytojo (5 pav.). Lankstumas ir derinimasis (šiuo atveju odontologo padejejejo prie gydytojo odontologo) priskiriamas emocinio intelekto kompetencijai (8):

Kiekvienas gydytojas, kiekviena klinika dirba pagal individualia tvarka. Pagrindinis siekis - absolventai turi būti lankstūs ir derintis prie gydytojo, su kuriuo jie dirba (PO3). Jiems (absolventams) reikia derintis prie kiekvieno gydytojo individualiai ir mokytis (PO7). O visa kita yra prisitaikymas. $<\ldots>>$ adaptuojamasi konkrečioje darbo vietoje (PO4). Ne visiems gydytojams patinka, kad odontologo padejejas kalba su pacientais. Čia yra individualu. Odontologams, kurie padèjejja priima kaip komandos nari, patinka komunikacija. Kiti < ...> nenori, kad jis įsiterptu. Taigi, dang kas priklauso nuo gydytojo požiūrio ir nuo vietos, kurioje dirbi (PO9).

Vydūno filosofinių idèjų bei principų sistemoje dažnai akcentuojama tolerancija, kilusi pirmiausia iš pačios mąstytojo filosofijos taikomojo pobūdžio, kaip viena iš žmogiškosios išminties veikimo momentų žmonių tarpusavio santykiuose (2). Ne mažiau svarbios ir kitos asmeninès savybès, grindžiamos humanizmo teorija, pagal kurią žmogus visuomenèje ịsitvirtina per veiklą, pažinimą ir pagal kurią žmogaus, kaip socialinès būtybès, santykis su socialine aplinka - jo išlikimo sąlyga.

Bendravimas ir kitos kompetencijos priskiriamos tęstinẻms gyvenimo bei darbo kompetencijoms, nesikoncentruojant ị konkrečią ugdymosi instituciją (6 pav.). Kompetencijos skirstomos ị bazines ir profesionalias. Bazinès - tai kiekvieno individo ịgimti ịūdžiai atlikti tam tikrą veiklą atitinkant minimalius reikalavimus. Išskiriamos keturios bazinių kompetencijų grupès: intelektualinè, motyvacinè, emocine, socialinè, kurias turi kiekvienas individas (8). Tačiau tai, ar šių kompetencijų grupių lygis yra bazinis ar profesionalus, lemia individo veiklos rezultatus. Studentai, ịstoję i aukštają mokyklą, turi skirtingą bazinị kompetencijų lygmenį, priklausomai nuo ịgimtų ir iki aukštosios mokyklos igytų kompetencijų, kurios formuojasi veikiant šeimai, mokyklai ir daugeliui kitų socializacijos veiksnių. Dèl bazinių kompetencijų tolimesnio plètojimo jas pagristai būtų galima vadinti tęstinèmis su profesionalumo perspektyva. Bendravimo ir kitų kompetencijų tęstinumą rodo ir ekspertų diskusija:

Bet tokio dalyko (bendravimo) neišmokysi (tik aukštojoje mokykloje) (PO2). Manau, tai (bendravimo kompetencija) kiekvieno žmogaus viduje, auklejime. $<\ldots>$ Bendravimo kolegijoje per 3 metus išmokyti yra beveik neimanoma (PO3). Man atrodo, kad mes iš absolventų tikimès per daug - iš karto reikalaujame aukščiausio lygio (PO7).

Burnos higienos ir Odontologinės priežiūros profesijų poliariškumas bei kompetencijų subalansavimo perspektyvos (7 pav.). Šioje kategorijoje pagal ekspertų diskusiją suformuotos dvi subkategorijos: „Platesnio profilio specialistai - kol kas neišpildytas šiuolaikinès rinkos poreikis“, „BH ir OP profesijų poliariškumas pagal atsakomybės ir sprendimų prièmimo kriterijų bei pagal absolventų ịsidarbinimą“. Pirmajai subkategorijai ekspertai skyrẻ šiek tiek daugiau dėmesio ir pateikè konkrečių idèjų:

Didelè absolventų dalis ìsidarbina pagal specialybę. Neabejoju tuo, kad odontologu padejejai randa darbo, bet manau, kad statistika neobjektyvi, kai kalbama apie burnos higienistus, nes daug ju dirba ne burnos higienistais, o odontologo padejejais. Todèl dabar jau reikia galvoti, kaip burnos higienistas galètu pagal praplèsta programa dalyvauti ir kaip gydytojo odontologo padejejas (PO3).

Naujų, progresyvių edukacinių sričių plètotė ir atitinkamų kompetencijų stiprinimas (8 pav.). Diskusijoje buvo išreikšti pastebejjimai ir sukurtos subkategorijos naujoms besiplètojančioms edukacinèms sritims gydytojo odontologo padejejų bei burnos higienistų darbo baruose: „Besilaukiančių moterų burnos higienos ir odontologijos poreikių atliepimas - tendencingai stiprejanti darbo sritis" ir „Edukacinis bendradarbiavimas su vaikų darželių ugdytiniais - perspektyvi darbo sritis“. Ekspertų teiginių koncentracija pagal šias dvi sritis nebuvo gausi, bet jų nuomone ịtikinanti:

Dabar labai populiarios pamokos besilaukiančioms küdikio moterims, tai turi didelę paklausą. Aš dalyvavau tokioje veikloje. Jauni žmonés viskuo labai domisi. Todèl absolventai šioje srityje turi būti stipriai pasiruoše (PO9). Savo klinikoje dirbantiems darbuotojams sudarome visas salygas 
ir skatiname finansiškai skaityti paskaitas bendruomenei (paskaitos ikimokyklinio amžiaus vaikams ir kitoms tikslinèms grupèms) (PO8).

Diskusijos apie absolventų kompetencijų atitiktį darbo rinkai poreikis ( 9 pav.). Diskusijos poreikiui apie absolventų kompetencijų atitiktị darbo rinkai ekspertai neliko abejingi:

Taip ir kolegijos dèstytojai, administracija gali sužinoti, ka galvoja darbdaviai ir teikti konkrečius realius pasiūlymus Odontologų rūmams (PO3). Gerai, kad tai yra organizuojama. Džiaugiuosi, nes tokie susitikimai duoda naudos (PO1). Tema yra aktuali (PO5).

Visi ekspertai, pasisakę apie diskusijos poreikị, išreiškẻ pritarimą ir palaikymą organizuojamai apskritojo stalo diskusijai apie absolventų kompetencijų atitiktį darbo rinkai.

\section{Išvados}

1. Kompetencija - profesiškai reikšmingų žinių, mokèjimų, ịūdžių, patyrimo, požiūrių, asmeninių charakteristikų ir vertybių visuma. Studentų kompetencijos ir jų ugdymas tampa vienu iš pagrindinių aukštojo mokslo egzistencijos ir studijų kokybės konglomeratų. Mokslinè darbo rinkos ir studijų programų ryšio analizè turi potencialių galimybių suteikti tobulinimo kryptis, kad išugdytos Odontologinès priežiūros ir Burnos higienos studijų programų absolventų kompetencijos kuo labiau atitiktų šiandieninès darbo rinkos poreikius.

2. Focus grupès tyrimo metodas interaktyviu būdu ịgalino lanksčiai prieigai analizuojant Klaipèdos valstybineje kolegijoje ruošiamų odontologinès priežiūros ir burnos higienos specialistų kompetencijas ir suteikè galimybę rasti atsakymus ị tyrimo tikslą. Kontentinès analizès būdu išryškejo šios kategorijos: „Aukštojoje mokykloje igyti profesinès kompetencijos pradmenys ugdomi ir tobulinami bedirbant" (19 teiginių), „Socialinė kompetencija koncentruojasi profesinio bendravimo su klientais ir kolegomis segmente" (19 teiginių), „Bendrujų kompetencijų tobulinimo perspektyvos“ (6 teiginiai), „Absolventų motyvacijos svarba jų kompetencijų plètotei - prioritetiné vertybe்“ (6 teiginiai), „Emocinio intelekto kompetencija orientuota ị lankstumą ir prisitaikymą prie gydytojo“ (6 teiginiai), ,Bendravimas ir kitos kompetencijos priskiriamos tęstinèms gyvenimo bei darbo kompetencijoms, nesikoncentruojant ị konkrečią ugdymosi instituciją“ (5 teiginiai), „Burnos higienos ir odontologinès priežiūros profesijų poliariškumas ir kompetencijų subalansavimo perspektyvos“ (5 teiginiai), „Naujų, progresyvių edukacinių sričių plètotè ir atitinkamų kompetencijų stiprinimas“ (4 teiginiai), „Diskusijos apie absolventų kompetencijų atitiktį darbo rinkai poreikis" (7 teiginiai).

3. Ekspertų diskusija koncentruojasi šiose iš kategorijų sudarytose pagrindinèse subkategorijose: „Prioritetas profesinio bendravimo kompetencijai” (9 teiginiai), „Praktiniu igūdžių poreikis ir praktikos galimybės“ (6 teiginiai), „To- bulinimosi motyvacijos siekiamybè - nuolat besimokančios visuomenès poreikis“ (4 teiginiai), „Darbo komandoje kompetencijos svarba ir plètoté" (4 teiginiai). Visos kitos 23 subkategorijos suformuotos iš mažesnès koncentracijos ekspertų pasisakymų (po 2-3 teiginius).

\section{Literatūra}

1. Plèšnys A. Socialinès filosofijos pagrindai. Vilnius. Vilniaus universiteto leidykla, 2016.

2. Bagdonavičius V., Martišiūtè-Linartienè A. Vydūnas: monografija. Vilnius. Mokslo ir enciklopedijų leidybos centras, 2017.

3. Laužackas R. Kompetencijomis grindžiamų mokymo/studijų programų kūrimas ir vertinimas: monografija. Kaunas. Vytauto Didžiojo universiteto leidykla, 2008.

4. Harari Y. N. 21 pamoka XXI amžiui. Vilnius. Kitos knygos, 2019.

5. Tamulienè R., Mačiulienė D., Žukauskaitè V. Gydytojų odontologų padejejjų pasitenkinimas darbu ir jị lemiantys veiksniai. Sveikatos mokslai, 2016; 6(26):231-236.

6. Šatrauskaitė R., Tamulienė R., Mačiulienè D. Gydytojų odontologų padejejjų darbe patiriamas stresas. Sveikatos mokslai, 2014; 6(24):51-56.

https://doi.org/10.5200/sm-hs.2014.112

7. Gaižauskaitė I., Valavičienė N. Socialinių tyrimų metodai: kokybinis interviu. Vilnius. Registrų centras, 2016.

8. Raudeliūnienė J. Žinių vadybos procesai ir jų vertinimas. Vilnius. VGTU leidykla „Technika“, 2016.

9. Profesionalioji burnos higiena: mokomoji knyga. J. Zūbienè, K. Saldūnaité, V. Andruškevičienè ir kt. Kaunas. LSMU Leidybos namai, 2017.

10. Berlin V., Pūrienè A., Dulkè G. 2016. Assistance for Dentists in Lithuania. Sveikatos mokslai, 2016; 6(26):155-160.

11. Rudènienè V., Šarkiūnienè M. Ergonomikos svarba gydytojo odontologo padejejjo darbe. Slauga, 2014; 4(208):9-12.

12. Pukelis K., Pileičikienè N. Aukštujų mokyklų absolventų išsiugdytų bendrujjų kompetentingumų ir darbo rinkos poreikių atitiktis. Aukštojo mokslo kokybè, 2012; 9:140-167.

13. Block P. Nepriekaištingas konsultavimas. Kaip paskatinti naudotis jūsų kompetencija. Vilnius. Eugrimas, 2013.

14. Barzelis A., Barcytè L., Mažeikienė N. Tarpkultūrinès kompetencijos ugdymas ir raiška kooperuotose studijose (service-learning). Kooperuotų studijų sociokultūrinè adaptacija Lietuvoje: Mokslo studija. Šiauliai. Šiaulių universiteto leidykla, 2008; 262-327.

15. Tarpkultūrinès kompetencijos didinimas bei ịvairovès valdymo gebèjimų stiprinimas. R. Jančaitytè, N. Valavičienè, R. Augutienė, R. Prakapas. Vilnius. Mykolo Romerio universitetas, 2009. 
COMPLIANCE OF COMPETENCES WITH A LABOR MARKET NEEDS OF DENTAL ASSISTING AND

\section{DENTAL HYGIENE STUDY PROGRAM GRADUATES}

I.Spiriajevienė, K.Albrechtienė, J.Andruškienė

Key words: competences of graduates, Dental assisting study programme, Dental hygiene study programme, labor market needs, focus group study, content analysis, qualitative research.

Summary

Scientific literature, document analysis and focus group research were conducted to analyze the topic.

Aim - to analyze the attitude of employers / social partners towards the compliance of the competences of graduates of Dental assisting and Dental hygiene study programs to the needs with a labor market needs. Empirical data were collected during the round table discussion with employers / social partners. The study included 11 experts in the field of dentistry. Qualitative (content) analysis of empirical data was performed.

Results. After analyzing the data of qualitative research, the following categories have been distinguished: The basics of professional competence acquired at a higher education institution are developed and improved by working (19 statements); Social competence is concentrated in the segment of professional communication with clients and colleagues (19 statements); Prospects for improving general competences (6 statements); The importance of graduates' motivation for the development of their competences - priority value (6 statements); The competence of emotional intelligence is focused on flexibility and adaptation to the doctor (6 statements); Communication and other competences are attributed to continuing competence in life and work without focusing on a specific educational institution (5 statements); Polarity of dental hygiene and dental assisting professions and perspectives for balancing competences (5 statements); Development of new, progressive educational areas and strengthening of relevant competences (4 statements); Need of a discussion of the compliance of graduates' competences with a labor market (7 statements).

The discussion of the participants of the study focuses on the following main sub-categories: "Priority for Professional Communication Competence" (9 statements), "Need for Practical Skills and Practice Opportunities" (6 statements), "The Purpose of Improvement Motivation - the Need for a Permanent Learning Society" (4 statements), "Work importance and development of excellence in the team"(4 statements).

The formation of all other subcategories was determined by lower concentration of respondents' claims (2-3 statements).

Correspondence to: spiriajeviene@gmail.com

Gauta 2019-03-19 